\title{
TAWAZUN
}

JURNAL PENDIDIKAN ISLAM

http://ejournal.uika-bogor.ac.id/index.php/TAWAZUN

Vol. 12, No. 1, Juni 2019, e-ISSN: 2654-5845, hlm. 20-35

DOI: 10.32832/tawazun.v12i1.1902

\section{Pendidikan Ibadah Muhammad Hasbi Ash- ShIddieQY}

\author{
Abdul Kahar \\ Sekolah Tinggi Ilmu Tarbiyah Muhammadiyah Aceh Barat Daya, Indonesia \\ abdul.kahar@gmail.com
}

\begin{abstract}
This research is focused on Muhammad Hasbi Ash Shiddieqy's Thinking of Religious Education. Specifically in religious education resources, purpose, curriculum, method, evaluation, its relevance to Islamic education, these cases is an effort to find how is religious education concept in Islamic education contexts. To get the data, the writer used library research that founded sources of data from various readings either primer or secondary data. After researching data then it analyzed by using data analysis method (content analysis or istimbathiyah) to describe the real communication content objectively, systematically and quantitatively in getting resources of primer and secondary sources. The result of this research will find very ideal concept formulation, which has relation with religious education according to Muhammad Hasbi Ash Shiddieqy. The characteristic of this thinking will be appear well from various aspects such as; cognitive, affective, and piskomotoric. He said that religious education is an effort in giving awareness to human beings so that to obey in Allah. While the aim of religious education is to be 'abid (Allah people) that obey him. In religious curriculum, he devided two kinds of religious, they are; mahdah and ghairu mahdah also there are two methods namely targhib and tarhib and the religious education is the last valuation of a human being, he changed or not his moral is very determined in doing worship, that is all depend on belonging knowledge and it will get in Islamic education.
\end{abstract}

Keywords: Muhammad Hasbi Ash Shiddieqy's; Religious; Education

\begin{abstract}
ABSTRAK
Fokus penelitian ini adalah pemikiran pendidikan Muhammad Hasbi Ash Shiddieqy mengenai landasan pendidikan ibadah, tujuan, kurikulum, metode, evaluasi dan relevansinya terhadap pendidikan Islam. Hal ini sebagai usaha untuk melihat bagaimana konsep pendidikan ibadah dalam konteks pendidikan Islam. Pendekatan yang digunakan dalam mencari data pada penelitian ini adalah studi riset kepustakaan (library research) dengan tahapan pokok yang menelusuri sumber-sumber data dari berbagai bacaan baik yang bersifat primer maupun yang bersifat skunder. Setelah penelusuran data dilakukan, maka akan dianalisis dengan menggunakan metode analisis data (content analysis atau istimbathiyah), berupa pelukisan isi komunikasi yang nyata
\end{abstract}


secara objektif, sistematik dan kualitatif terhadap bahan yang didapati dari sumber data primer dan skunder. Hasil penelitian ini akan menemukan formulasi konsep yang sangat ideal terkait dengan pendidikan ibadah menurut seorang ulama figh seperti Muhammad Hasbi Ash Shiddieqy. Karakteristik pemikiran ini akan terlihat baik dari segi kognitif, afektif, maupun psikomotorik. Muhammad Hasbi Ash Siddieqy mengatakan, pendidikan ibadah merupakan usah memberi kesadaran kepada manusia untuk taat kepada Allah. Sedangkan tujuan pendidikan ibadah adalah untuk menjadi 'abid (hamba Allah) yang taat. Dalam kurikulum ibadah Hasbi membagi dua macam yaitu ibadah mahdah dan ghairu mahdah, metode juga Hasbi membentuk dua metode yaitu metode targhib dan tarhib adapun evaluasi ibadah merupakan penilaian akhir seorang hamba berubah atau tidaknya itu sangat ditentukan oleh ibadah yang dilakukan. Tentu semua itu juga tergantung ilmu yang dimiliki, dan ilmu akan didapatkan dalam pendidikan Islam.

Kata kunci : Muhammad Hasbi Ash Shiddieqy; pendidikan; ibadah

\section{Pendahuluan}

Pendidikan suatu hal yang amat penting dan harus diperhatikan oleh setiap negara, karena pendidikan akan memajukan suatu bangsa dan negara. Adapun pendidikan nasional bertujuan untuk meningkatkan kualitas manusia Indonesia, yaitu manusia yang beriman dan bertakwa terhadap Tuhan Yang Maha Esa, berbudi pekerti luhur, berkepribadian mandiri, maju, tangguh, cerdas, kreatif, terampil, berdisiplin, beretos kerja, profesional, bertanggung jawab dan produktif serta sehat jasmani dan rohani. Sehingga ia mampu membangun dirinya dan masyarakat sekelilingnya serta dapat memenuhi kebutuhan pembangunan nasional dan bertanggung jawab atas pembangunan bangsa. (Indonesia, 1993)

Pendidikan merupakan hak setiap warga Negara. Oleh karena itu peningkatan mutu pendidikan merupakan bagian yang tidak terpisahkan dari proses pengembangan sumber daya manusia, harus dilakukan secara terencana, terarah, dan intensif, sehingga mampu menyiapkan bangsa Indonesia memasuki era globalisasi yang sarat dengan persaingan. (Ikhtiono, 2018)

Pendidikan adalah proses pengembangan dan pembentukan manusia melalui tuntunan dan petunjuk yang tepat dalam segala aspek kehidupan. Tugas itu terutama dilimpahkan kepada manusia pada tingkatan yang berbeda. Jadi, pendidikan berarti suatu proses pengembangan dan penuntun kecerdasan manusia untuk mencapai kematangan dan derajat yang dicita-citakan. Manusia tak akan bisa hidup teratur dan hidup baik tanpa pendidikan, inilah yang mengarahkan manusia kepada kebenaran yang dapat mengatur hidupnya lebih sempurna. 
Pendidikan yang berbasis agama akan memberikan perlindungan rasa aman, kenyamanan, ketenangan batin dan ketenteraman diri dalam mengisi tata laku keseharian dalam kehidupan. Semakin kurang ilmu agamanya semakin jauh manusia dari sang khalidnya, apa lagi tidak mempunyai ilmu agama sedikit pun tidak bisa di bayangkan, sementara kita lihat di zaman sekarang ini, juga sangat banyak orang-orang yang sudah berilmu pun rentan melakukan kecurangan-kecurangan dan kedhalimankedhaliman ini menandakan ilmu tidak berkecukupan, hanya kepintaran dari satu sisi sementara sisi keagamaan tidak ditanamkan semestinya.

Rasa iman dan takwa jauh lebih ditinggalkan, maka di sinilah sangat diperlukan bimbingan dan pendidikan agama yang lebih baik dalam rangka menjadikan manusia hidup yang sesuai dengan apa yang diharapkan oleh sang pencipta. Apalagi menyangkut hubungan dengan sang pencipta, membutuhkan tatanan ilmu pengetahuan yang memadai dan cukup untuk menempuh kesuksesan seorang hamba menjumpai sang khaliqnya.

Secara historis pertumbuhan dan perkembangan pendidikan yang menyangkut dengan masalah pendidikan ibadah, sangat terkait erat dengan kegiatan dakwah Islamiyah. Pendidikan Islam dalam berbagai tingkatannya.

Melalui pendidikan inilah, masyarakat dapat memahami, menghayati dan mengamalkan ajaran Islam sesuai dengan ketentuan Al-Quran dan As-Sunah, khususnya menyangkut dengan ibadah itu sendiri, yang dilakukan dalam kehidupan sehari-hari. Sehubungan dengan itu, tingkat kedalaman pemahaman, penghayatan dan pengamalan masyarakat terhadap pelaksanaan ibadah, amat tergantung pada tingkat kualitas pendidikan dan pelajaran ibadah yang diterimanya. Pendidikan tersebut dapat berkembang sesuai dengan kemampuan dan keinginan seseorang dalam belajar dan mencari ilmu demi tercapainya tingkatan nilai ibadah yang lebih baik.

Berbicara tentang pemikiran pendidikan ibadah tentu sangat menarik sekali, karena pendidikan merupakan sumber utama untuk memperbaiki moralitas manusia dan pendidikan tidak bisa dipisahkan dari manusia itu sendiri. Dilihat dari berbagai sisi aturan dan tata cara kehidupan masyarakat masih banyak yang tidak paham dengan tatalaksana kehidupan yang sempurna, maka dari itu sangat perlu bimbingan dan arahan melalui pendidikan-pendidikan yang bisa dijadikan sumber perubahan masa depan.

Walaupun masyarakat telah mempunyai kebudayaan-kebudayaan lain yang mempengaruhi namun para tokoh-tokoh dapat pula memunculkan pendapat baru. Karena itu kita mendapati dua penyebab yang mempengaruhi perkembangan pendidikan di daerah-daerah. Pertama lingkungan dan kedua sistem yang ditempuh oleh para pendidik dan perancang pendidikan.

Dalam pembahasan ini penulis mengungkap pemikiran Hasbi Shiddieqy tentang pendidikan ibadah, karena itu diperlukan perhatian bagaimana seorang mukmin melakukan ibadah tanpa memiliki ilmu yang cukup tentang ibadah itu sendiri. Untuk 
mendapatkan ilmu dalam ibadah itu harus membutuhkan pendidikan yang baik dan dari sumber yang jelas, tanpa ada rasa ketidakpedulian terhadap ilmu yang memang wajib untuk dipelajari supaya dalam mengamalkannya tidak ada yang merasa keliru.

Landasan dan dasar pendidikan ibadah yang dikemukakan oleh Prof. Dr. Teungku Muhammad Hasbi Ash Shidieqy berlandaskan kepada Al-Qur'an dan Al-Sunah, benarbenar digunakan sebagaimana mestinya. Dengan atas dasar itulah penulis munculkan kembali tokoh masa silam yang dapat kita jadikan sumber pendidikan yang merujuk kepada Al-Qur'an dan Assunnah, supaya kita dapat menemukan titik keberhasilan dalam melaksanakan ibadah itu sendiri

Sebagaimana yang diharapkan, Pendidikan dalam ibadah ini, sangat amat penting dikaji melalui pengkajian dan pemikiran tokoh-tokoh yang sudah terkenal dan populer, bahkan tulisan dan pemikirannya dapat diterima oleh kalangan masyarakat luas, dan layak di jadikan sebagai sumber pengetahuan baik kehidupan dunia maupun akhirat. Tokoh yang hendak penulis kajikan pada artikel ini adalah Muhammad Hasbi Ash shidieqy yang sudah pernah populer tulisannya yaitu tentang pemikirannya tentang banyak hal dalam ilmu-ilmu lbadah khususnya.

Setelah penulis telusuri, belum ditemukan karya tulis yang membahas sama persis dengan tema yang sedang diteliti. Atas dasar itulah, penulis menggali konsep pendidikan ibadah Muhammad Hasbi Ash Shiddieqy, sehingga bisa dijadikan sumber pengembangan ilmu pendidikan ibadah di kalangan akademisi dan masyarakat.

\section{Metode Penelitian}

Penelitian ini berkaitan dengan pemikiran Muhammad Hasbi Ash Shiddieqy yaitu ulama yang hidup di era kemerdekaan. Metode yang digunakan adalah metode kualitatif, di mana data-data dikumpulkan dengan cara mengumpulkan sumber-sumber tertulis berupa dokumen dalam bentuk buku-buku dan dokumen lainnya. Metode yang digunakan dalam mencari data kepustakaan (library research), yaitu dengan cara menelusuri sumber-sumber data dari berbagai bacaan, baik yang bersifat primer maupun skunder. Kajian kepustakaan ini bertujuan untuk mengumpulkan data dan informasi dengan bantuan macam-macam material yang terdapat di perpustakaan, baik yang bersifat manual, maupun digital.

Setelah penelusuran data dilakukan, akan dianalisis dengan menggunakan metode analisis isi (content analysis atau istimbathiyah) yaitu berupa pelukisan isi komunikasi yang nyata secara objektif, sistematik, dan kualitatif terhadap bahan-bahan yang didapat dari sumber data primer dan sekunder. Sebagaimana dikemukakan oleh Hosti (1969), bahwa content analysis adalah teknik apa pun yang digunakan untuk menarik kesimpulan melalui usaha menemukan karakteristik pesan, dan dilakukan secara objektif dan sistematis. 
Penelitian ini mengambil objek ide yang merupakan gagasan atau pemikiran Muhammad Hasbi Ash Shiddieqy tentang pendidikan ibadah, yang termuat secara mendalam dalam karya-karyanya. Sumber data penelitian ini terdiri dari dua sumber, yaitu sumber primer (primary sources) dan sumber skunder (secondary sources). Adapun sumber primer diambil dari karya-karya Muhammad Hasbi Ash Shiddieqy yang berhubungan langsung dengan masalah pendidikan Ibadah. Karya-karya tersebut adalah: a. Kuliah Ibadah, Ibadah Ditinjau Dari Segi Hukum dan Hikmah, Pedoman Shalat, Sejarah dan Pengantar Ilmu Al-Qur'an dan Tafsir, Pengantar Fiqih Muamalah.

\section{Hasil dan Pembahasan}

\section{A. Temuan Penelitian}

Muhammad Hasbi Ash Shiddieqy lahir di Lhokseumawe, Aceh Utara 10 Maret 1904 di tengah keluarga ulama pejabat. Dalam tubuhnya mengalir darah campuran Arab. Dari silsilahnya diketahui bahwa beliau keturunan ke-37 dari Abu Bakar ash-Shiddieq. Anak dari pasangan Teungku Amrah, puteri Teungku Abd Al-Aziz pemangku jabatan Qadhi Chik Maharaja Mangkubumi dan Al-Hajj Teungku Muhammad Husen ibn Muhammad Mas'ud. (Shiddieqy, 2010)

Pada masa awal persiapan kemerdekaan Republik Indonesia, perbincangan tentang hukum Islam dari aspek fiqh semakin surut karena semua umat Islam disibukkan dengan pembentukan Negara Kesatuan Republik Indonesia (NKRI). Namun, kesibukan tersebut tidak pernah membuat Hasbi ikut terlena untuk melupakan agenda pembaruan hukum Islam di Indonesia kendatipun banyak para pembaru Muslim di masanya yang mendirikan organisasi-organisasi kemasyarakatan (Ormas).

Berdasarkan hal tersebut, wacana yang dikembangkan dalam pemikiran keislaman menjadi kurang empiris dan mengakibatkan terbengkalainya sederet nomenklatur permasalahan sosial-politik yang terjadi di masyarakat, yang telah menggerakkan Soekarno untuk ikut memberikan kritik terhadap kerangka pikir yang selama ini dipakai oleh para ulama. Kungkungan pola pikir para ulama yang berpacu pada fahm-u \% ‘ilm li \%-inqiyâd ketika memahami doktrin hukum Islam yang terdapat di dalam khazanah literatur klasik membuat eksistensi hukum Islam tampak resistan, tidak mampu mematri diri, dan sebagai konsekuensinya ia menjadi pancera bagi persoalan sosial-politik. Para ulama secara umum telah melupakan sejarah dan menganggap bahwa mempelajari sejarah tidaklah begitu penting sehingga kritik atas dimensi ini menjadi tidak ada. Dengan demikian, pandangan mereka terhadap fiqh adalah sebagai kebenaran ortodoksi mutlak, yang absolutitasnya menegasikan kritik dan pengembangan, dan bukan sebagai pemikiran yang bersifat nisbi, yang membutuhkan kritik dan pengembangan. Maka, perlulah sebuah pemikiran dan pandangan baru yang dapat menggeser paradigma dari pola fahm-u \% "ilm li \%-inqiyâd ke pola fahm-u 'ilm li \% intiqâd. 
Dari titik berangkat kenyataan sosial dan politik seperti itulah pemikiran figh Indonesia hadir, ia terus mengalir dan disosialisasikan oleh Hasbi. Menurutnya, hukum Islam harus mampu menjawab persoalan-persoalan baru, khususnya dalam segala cabang dari muamalah, yang belum ada ketetapan hukumnya. la harus mampu hadir dan bisa berpartisipasi dalam membentuk gerak langkah kehidupan masyarakat. Para ulama (lokal) dituntut untuk memiliki kepekaan terhadap kebaikan (sense of mashlahah) yang tinggi dan kreativitas yang penuh dengan tanggung jawab dalam upaya merumuskan alternatif fiqh baru yang sesuai dengan situasi dan kondisi masyarakat yang dihadapinya.

Nalar pemikiran yang digunakan oleh Hasbi dengan gagasan fiqh Indonesia adalah satu keyakinan bahwa prinsip-prinsip hukum Islam sebenarnya memberikan ruang gerak yang lebar bagi pengembangan dan ijtihad-ijtihad baru. Menurutnya, hingga tahun 1961, salah satu faktor yang menjadi penghambat adalah adanya ikatan emosional yang begitu kuat (fanatik, ta'ashshub) terhadap mazhab yang dianut oleh umat Islam. Dan untuk membentuk figh baru ala Indonesia, diperlukan kesadaran dan kearifan lokal yang tinggi dari banyak pihak, terutama ketika harus melewati langkah pertama, yaitu melakukan refleksi historis atas pemikiran hukum Islam pada masa awal perkembangannya. Perspektif ini mengajarkan bahwa hukum Islam baru bisa berjalan dengan baik jika ia sesuai dengan kesadaran hukum masyarakat. Yakni, hukum yang dibentuk oleh keadaan lingkungan atau dengan kebudayaan dan tradisi setempat (adat dan 'urf), bukan dengan memaksakan format hukum Islam yang terbangun dari satu konteks tertentu kepada konteks ruang dan waktu baru. Maka, kita dapat menyimpulkan bahwa ide figh Indonesia yang telah dirintis olehnya berlandaskan pada konsep bahwa hukum Islam (fiqh) yang diberlakukan untuk umat Islam Indonesia adalah hukum Islam yang sesuai dan memenuhi kebutuhan rakyat Indonesia, selama itu tidak bertentangan syari'at.

Dalam pandangan Hasbi, pemikiran hukum Islam harus berpijak pada prinsip mashlahah mursalah, keadilan, kemanfaatan, serta sadd-u '/-zarî‘ah. Semua prinsip itu, merupakan prinsip gabungan dari setiap madzhab. Maka, untuk memberikan pemahaman yang baik, ia menawarkan metode analogi-deduktif -satu model istinbat hukum yang pernah dipakai oleh Imam Abû Hanîfah - untuk membahas satu permasalahan yang tidak ditemukan ketentuan hukumnya dalam khazanah pemikiran klasik. Dengan demikian, untuk memudahkan penerapan metode di atas, ia menggunakan pendekatan sosial-kultural-historis dalam segala proses pengkajian dan penemuan hukum Islam.

Salah satu contoh kasus, adalah perdebatan Hasbi dengan A. Hasan tentang boleh tidaknya jabat tangan antara laki-laki dan perempuan. Terlepas dari tidak adanya dalil pasti dan alasan yang rasional tentang pengharaman jabatan tangan antara laki-laki dan perempuan maka ia berpendapat bahwa tradisi jabat tangan antara laki-laki dan perempuan bukan sesuatu yang berbahaya untuk dilakukan. (Shiddieqy, 1994). Dalam sisi lain tentang masalah ibadah shalat Hasbi mengatakan, sebesar-besar ibadat yang mendekatkan para 'abid (hamba) kepada ma'budnya (sebesar-besar persembahan yang 
dipersembahkan hamba kepada Tuhannya), dan seteguh-teguh shilat (perhubungan) yang menghubungkan makhluq, manusia dengan khaliqnya, perlulah diberikan semua contoh-contoh yang baik, istimewa para penuntun dan para pembimbing memberikan tuntunan dan pimpinan yang sempurna, kepada rakyat, saudara-saudara yang mengerjakan shalat dengan tata tertib yang jauh dari nizham (aturan) yang benar, jauh dari cara yang diperbuat Rasul saw.

Dari hal tersebut maka, Hasbi Ash Shiddieqy menguraikan beberapa item yang mengulas tentang pendidikan ibadah agar dapat menemukan titik tolak ukur dalam pengembangan diri seorang hamba terhadap sang pencipta.

\section{Pengertian Pendidikan Ibadah}

Pendidikan ibadah adalah suatu usaha untuk memberikan kesadaran beribadah kepada manusia agar mengerti tentang eksistensi dirinya sebagai seorang hamba Allah. Dengan tunduk yang setinggi-tingginya.(Shiddieqy, 2010)

\section{Landasan Pendidikan Ibadah}

Segala gerak langkah manusia dalam menjalani kehidupan ini, tentu tidak dapat dipisahkan dengan kehidupan kemajemukan, dalam arti tidak dapat hidup berdiri sendiri melainkan harus saling berhubungan antara satu dengan yang lainnya. Dengan menjaga kehidupan yang baik dan sempurna maka hidup yang demikian itu berarti hidup dalam sisi ibadah.(Kulsum, 2002)

Dalam pelaksanaan ibadah Hasbi Ash Siddieqy mengatakan, ada dua landasan dasar pendidikan ibadah sebenarnya tidak lain dari dasar ajaran Islam, yaitu Al-Qur'an dan al-Hadits.

\section{a. Al-Qur'an}

Menurut Hasbi Ash-Shiddieqy al-Qur'an mengandung makna yang luas dan banyak pendapat tentang pengertiannya itu, ringkasnya dapat dikatakan bahwa Al-Qur'an itu Wahyu llahi yang diturunkan kepada Muhammad saw. yang telah disampaikan kepada umatnya dengan jalan mutawatir, yang di hukum kafir orang-orang yang mengingkarinya. (Shiddieqy, 2012)

Dari padanya diambil segala pokok-pokok syari'at dan cabang-cabangnya. Juga dari padanya dalil-dalil syar'i mengambil tenaganya. Dengan demikian dipandang bahwa Al-Qur'an itu dasar yang kulli bagi syari'at dan pengumpul segala hukum. Allah swt. berfirman:

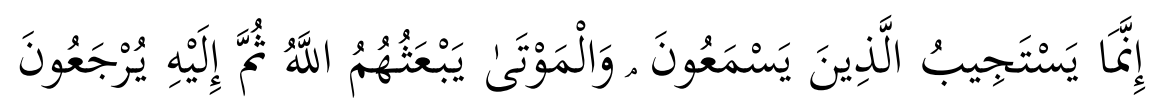

“Tidaklah kami alpakan sedikit pun dalam Al-Kitab”. (QS. Al-An’am[6]: 38). 
Al-Qur'an merupakan landasan sekaligus sumber ajaran Islam, secara keseluruhan sebagai pola hidup dan menjelaskan apa yang harus diperbuat dalam kehidupan manusia untuk mencapai kebahagiaan dunia dan akhirat. (Razak, 1984)

Al-Qur'an bukan hasil rekayasa manusia, ia semata-mata Firman Allah Swt. yang diturunkan kepada Nabi Muhammad saw. hal ini dinyatakan sendiri oleh Alllah SWT. dalam surat Al-Maidah ayat 16 sebagai berikut:

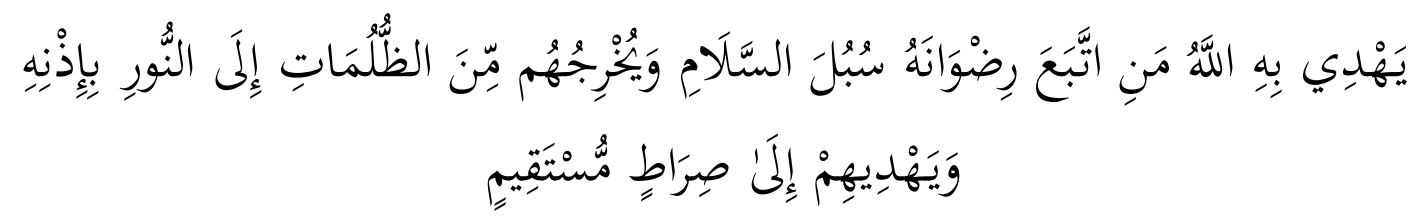

"Dengan kitab Itulah Allah menunjuki orang-orang yang mengikuti keredaan-Nya ke jalan keselamatan, dan (dengan kitab itu pula) Allah mengeluarkan orang-orang itu dari gelap gulita kepada cahaya yang terang benderang dengan seizin-Nya, dan menunjuki mereka ke jalan yang lurus". (QS. Al-Maidah: 16).

Al-Qur'an adalah petunjuk-Nya yang apabila dipelajari akan membantu kita menemukan nilai-nilai yang dapat dijadikan pedoman bagi penyelesaian berbagai problem hidup. Apabila dihayati dan diamalkan akan menjadi pikiran, rasa dan karsa dan mengarah pada realitas keimanan yang dibutuhkan bagi stabilitas dan ketenteraman hidup pribadi dan masyarakat.(Shihab, 1998)

Pendidikan ibadah diterangkan dalam beberapa ayat, di antaranya yang dijadikan konsepsi pada penelitian ini, yaitu surat Ali-Imran ayat 56-58. Tentang bagaimana Nabi Isa mengajak kaum untuk menyembah Allah dan mengikuti ajaran Rasul serta balasan yang diberikan pada orang beriman dan tidak beriman.

\section{b. Al-Hadits}

Hadits merupakan penafsiran Al-Qur'an dalam praktik ataupun penerapan ajaran Islam secara faktual dan ideal. Hal ini mengingatkan bahwa pribadi Nabi saw. merupakan perwujudan dari Al-Qur'an yang ditafsirkan untuk manusia serta ajaran Islam yang dijabarkan dalam kehidupan sehari-hari.(Qardhawi, 1993)

Dalam lapangan pendidikan, Al-Hadits mempunyai dua faedah yang sangat besar yaitu:

1. Menjelaskan sistem pendidikan Islam yang terdapat di dalam Al-Qur'an dan menerangkan hal-hal kecil yang tidak terdapat di dalamnya.

2. Menyimpulkan metode pendidikan dari kehidupan Rasulullah saw. bersama para sahabatnya, perlakuannya terhadap anak-anak dan penanaman keimanan ke dalam jiwa yang dilakukan.(Nahlawi, 1989) 
Sedangkan pengertian Hadits itu sendiri mengandung empat unsur, yakni perkataan, perbuatan, pernyataan, dan sifat-sifat atau keadaan-keadaan Nabi Muhammad saw. yang lain, yang semuanya disandarkan Nabi saja, tidak termasuk hal-hal yang disandarkan kepada sahabat dan tidak pula kepada tabi’in.(Rahman, 1991)

Hadits adalah dasar hukum Islam yang kedua setelah Al-Qur'an. Hadits menjelaskan secara terperinci hal-hal yang ada dalam Al-Qur'an yang sifatnya masih global atau masih berupa perumpamaan, karena Al-Qur'an di ciptakan oleh Allah berupa ajaranajaran yang masih global agar dapat diterapkan dalam berbagai masa dan keadaan, semua ajaran Islam yang belum dijelaskan dalam Al-Qur'an secara terperinci diuraikan oleh Nabi baik lewat perkataan, perbuatan dan pernyataan.

Pendidikan ibadah ini juga diterangkan dalam beberapa hadits Nabi saw. di antaranya adalah:

Ibnu Abi Umar telah menceritakan kepada kita, Sofyan bin Uyainah dari Su'air bin Khimsi at-Tamimi dari Habib bin Abi Tsabit dari lbnu Umar berkata: Rasulullah saw. bersabda: Islam dibangun atas lima dasar: membaca syahadat (bersaksi) bahwa sesungguhnya tidak ada Tuhan selain Allah dan sesungguhnya Nabi Muhammad itu adalah utusan-Nya, mendirikan shalat, membayar zakat, puasa bulan Ramadhan, dan naik haji ke Baitullah”.(Tirmidzi, n.d.)

Dalam Hadits di atas tersirat makna bahwa kita sebagai umat Nabi Muhammad saw. diperintahkan agar mempercayai dan meyakini bahwa tiada Tuhan selain Allah dan Nabi Muhammad adalah utusan-Nya, hal itu diikuti dengan mempercayai ciptaan Allah dan semua yang akan terjadi di alam semesta.

\section{Tujuan Pendidikan Ibadah}

Tujuan pendidikan ibadah merupakan upaya untuk mendapatkan ilmu tentang ibadah itu sendiri bagi manusia, agar dapat melaksanakan ibadah dengan sempurna. Sebab, dalam kegiatan apa pun bentuknya pasti akan memiliki tujuan. Hal itu wajib untuk dilakukan. Karena, ibadah merupakan kewajiban manusia untuk melaksanakannya atas perintah Allah SWT. maka dari itu, Hasbi Ash Shiddieqy mengatakan bahwa ada tiga tujuan dalam melaksanakan ibadah yaitu:

a. Ibadah adalah Hak Allah dan Wajib Dipatuhi.

Ibadah adalah jalan mensyukuri nikmat Allah. Atas dasar inilah, tidak diharuskan bagi manusia, baik oleh syara' maupun akal untuk beribadah kepada selain Allah. Karena Allah sendiri yang berhak menerimanya, sebab Allah sendiri yang memberikan nikmat yang paling besar kepada makhluk, yaitu hidup, wujud dan semua hal yang berhubungan dengannya. Dan yakin dengan seyakin-yakinnya, bahwa Allah yang memberikan nikmat kepada seluruh makhluk. Maka mensyukuri nikmat yang telah diberikan itu wajib. Dengan yakin pula, bahwa Tuhan menimbulkan bencana atas hamba-Nya di dalam dunia ini dan akan memberi balasan yang setimpal di akhirat kelak 
kepada mereka yang taat dan maksiat masing-masing menurut yang layak mereka peroleh.

b. Ibadah Ghayah (tujuan) Hidup Manusia

Hasbi Ash Shiddieqy menjelaskan bahwa, ibadah adalah ghayah (tujuan) dijadikannya jin, manusia dan makhluk lainnya. Allah Swt. berfirman:

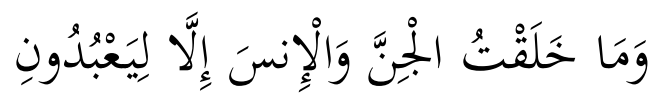

Aku tidak jadikan jin dan manusia, melainkan supaya beribadah kepada-Ku”. (QS. Adz-Dzariyat: 56).

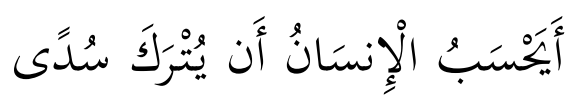

“Apakah manusia mengira bahwa manusia itu akan dibiarkan demikian saja”. (QS.

Al-Qiyamah: 36).

Asy-Syafi'i mengatakan, makna ayat tersebut ialah apakah manusia mengira bahwa mereka tidak diperintah dan dilarang? Mereka disuruh dan dilarang. Atas dasar itulah berlaku pahala dan siksa. Mengerjakan perintah dan menjauhi dosa adalah inti ibadah. (Shiddieqy, 2010)

\section{c. Ibadah Sebagai Perintah}

Untuk mewujudkan ibadah seorang hamba, Tuhan memerintahkan hamba beribadah kepada-Nya. Tuhan mengeluarkan perintah-Nya tersebut, sebenarnya adalah suatu keutamaan-Nya yang besar kepada kita.

Jika direnungi hakikat ibadah, maka yakin bahwa perintah beribadah pada hakikatnya berupa peringatan bagi manusia untuk menunaikan kewajiban terhadap Maha yang telah melimpahkan karunia-Nya. Allah Swt. berfirman:

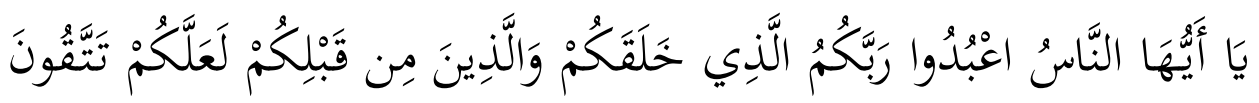

"Wahai segala manusia, beribadahlah kamu kepada Tuhanmu, yang telah menjadikan kamu dan telah menjadikan orang-orang yang sebelummu, supaya yang demikian itu menyiapkan kamu untuk bertakwa kepada-Nya”. (QS. Al-Baqarah: 21).

Dengan terang Nabi saw. menjelaskan bahwa ibadah adalah hak Allah yang wajib kita laksanakan dengan sewajarnya. Mu'adz ra. mengatakan:

"Pada suatu hari aku duduk di belakang Nabi atas kendaraannya (keledainya), maka beliau berkata: "Hai Mu'adz tahukah engkau apa hak Allah atas hamba dan hak hamba terhadap Allah? Aku menjawab: Allah dan Rasul-Nya yang lebih mengetahui. Berkata Nabi saw.: Hak Allah atas hamba, ialah mereka menyembah-Nya dengan 


\section{Abdul Kahar}

segala keesaan-Nya, dan mereka tidak menyekutukan-Nya dengan sesuatu. Dan hak hamba terhadap Allah, ialah Allah tidak akan mengazab orang yang tidak menyekutukan-Nya dengan sesuatu”. (HR. Bukhari dan Muslim ).

\section{Kurikulum Pendidikan Ibadah}

Kurikulum merupakan sebuah program untuk mencapai pada tingkat tujuan keberhasilan dalam melakukan sesuatu. Dalam pembahasan kurikulum pendidikan ibadah ini, Hasbi Ash Shiddieqy menjelaskan secara garis besar saja. Akan tetapi dapat diringkaskan dalam bentuk kurikulum yang lebih mengarah pada pokok-pokok pembahasan ibadah tersebut. Ibadah dapat dibagi dua sifat yaitu ibadah mahdah dan ghairu mahdah. Ibadah mahdhah atau ibadah khusus adalah ibadah yang apa saja yang telah ditetapkan Allah akan tingkat, tata cara dan perincian-perinciannya. Dan sedangkan ibadah ghairu mahdhah atau ibadah umum adalah segala amalan yang di izinkan oleh Allah. Perbedaan di antara keduanya adalah ibadah mahdhah wajib terus ditunaikan walaupun sudah lewat waktunya. Sedangkan ghairu mahdhah apabila sudah keluar waktunya, tidak diwajibkan lagi untuk menunaikannya. (Shiddieqy, 2010)

Tabel 1. Ibadah Mahdah dan Ghairu Mahdhah

\begin{tabular}{|c|c|c|c|}
\hline Ibadah Mahdah & & Ibadah Ghairu Mahdah & \\
\hline Bentuk & Contoh & Bentuk & Contoh \\
\hline $\begin{array}{l}\text { 1.lbadah yang } \\
\text { dikaitkan syara' } \\
\text { dengan waktu } \\
\text { tertentu dan } \\
\text { terbatas. }\end{array}$ & $\begin{array}{l}\text { Shalat dan puasa } \\
\text { Ramdhan. }\end{array}$ & $\begin{array}{l}\text { 1. Melaksanakan fardhu- } \\
\text { fardhu kifayah yang } \\
\text { bersangkutan dengan } \\
\text { kemaslahatan dunia } \\
\text { apabila diniatkan ibadah } \\
\text { akan mendapatkan } \\
\text { pahala. }\end{array}$ & $\begin{array}{l}\text { Membajak, } \\
\text { menanam, } \\
\text { menenun dan } \\
\text { bertukang } \\
\text { Sedekah }\end{array}$ \\
\hline $\begin{array}{l}\text { 2. Ibadah yang } \\
\text { tidak boleh } \\
\text { diqadha, kecuali } \\
\text { sama dalam } \\
\text { waktunya.- } \\
\end{array}$ & Ibadah haji & $\begin{array}{l}\text { 2. Melakukan sikap } \\
\text { kebersamaan sesama } \\
\text { mukmin yang } \\
\text { mengandung nilai ibadah }\end{array}$ & $\begin{array}{l}\text { Tolong } \\
\text { menolong }\end{array}$ \\
\hline $\begin{array}{l}3 \text { Ibadah yang } \\
\text { dilihat waktu } \\
\text { pelaksanaannya } \\
\text { bukan waktu } \\
\text { wajibnya }\end{array}$ & $\begin{array}{l}\text { Bersuci atau } \\
\text { berwudu }\end{array}$ & $\begin{array}{l}\text { 3. Berbuat amar makruf } \\
\text { nahi munkar yang } \\
\text { mengandung nilai ibadah }\end{array}$ & Berdakwah \\
\hline $\begin{array}{l}\text { 4. Ibadah yang } \\
\text { sudah ditetapkan } \\
\text { syara' sebagai } \\
\text { pengganti yang lain, } \\
\text { apabila tidak ada } \\
\text { saat dibutuhkan }\end{array}$ & $\begin{array}{l}\text { Tayamum } \\
\text { sebagai } \\
\text { pengganti air }\end{array}$ & $\begin{array}{l}\text { 4. Pekerjaan yang kita } \\
\text { lakukan dengan niat yang } \\
\text { mulia yang di akhirat } \\
\text { akan diberi balasan akan } \\
\text { mendapatkan satu derajat } \\
\text { di bawah Nabi }\end{array}$ & $\begin{array}{l}\text { Belajar } \\
\text { menuntut ilmu }\end{array}$ \\
\hline
\end{tabular}




\begin{tabular}{|c|c|c|c|}
\hline $\begin{array}{l}\text { 5. lbadah yang } \\
\text { dapat menghasilkan } \\
\text { dua bentuk ibadah } \\
\text { dengan sekali } \\
\text { pelaksanaan }\end{array}$ & $\begin{array}{l}\text { Umrah bisa } \\
\text { masuk dalam } \\
\text { haji. }\end{array}$ & $\begin{array}{l}\text { 5. Ibadah yang ringan } \\
\text { diberi balasan pahala oleh } \\
\text { Allah dan ampunan } \\
\text { apabila kita } \\
\text { melakukannya }\end{array}$ & $\begin{array}{l}\text { Menyingkirkan } \\
\text { duri di tengah } \\
\text { jalan }\end{array}$ \\
\hline $\begin{array}{l}\text { 6. Ibadah yang } \\
\text { telah diwajibkan } \\
\text { syara' untuk } \\
\text { melaksanakannya } \\
\text { sebelum melakukan } \\
\text { yang lain }\end{array}$ & Mandi hadas & $\begin{array}{l}\text { 6. Ibadah yang } \\
\text { disyariatkan untuk } \\
\text { kemaslahatan dunia dan } \\
\text { tidak bersangkut dengan } \\
\text { kemaslahatan akhirat } \\
\text { secara langsung }\end{array}$ & $\begin{array}{l}\text { Memberi } \\
\text { nafkah kepada } \\
\text { istri, }\end{array}$ \\
\hline $\begin{array}{l}\text { 7. Ibadah yang } \\
\text { tidak dikategorikan } \\
\text { pelaksanaannya } \\
\text { dengan ada' (saat } \\
\text { itu juga) dan tidak } \\
\text { dengan qada. }\end{array}$ & $\begin{array}{l}\text { Shalat-shalat } \\
\text { Sunah di luar } \\
\text { shalat wajib dan } \\
\text { zikir }\end{array}$ & $\begin{array}{l}\text { 7. Ibadah yang tidak } \\
\text { terputus pahalanya } \\
\text { diberikan oleh Allah }\end{array}$ & Sedekah \\
\hline $\begin{array}{l}\text { 8. lbadah-ibadah } \\
\text { yang dapat } \\
\text { dilaksanakan atas } \\
\text { dasar suatu syarat. }\end{array}$ & Nadzar & $\begin{array}{l}\text { 8. Ibadah yang kadarnya } \\
\text { tidak dibatasi oleh syara' }\end{array}$ & $\begin{array}{l}\text { Memberi } \\
\text { makan orang } \\
\text { lapar, memberi } \\
\text { pakaian kepada } \\
\text { orang yang } \\
\text { telanjang }\end{array}$ \\
\hline $\begin{array}{l}\text { 9. Ibadah yang } \\
\text { boleh diselesaikan } \\
\text { (diqadha) dalam } \\
\text { berbagai waktu }\end{array}$ & $\begin{array}{l}\text { Kurban dan } \\
\text { hadnya yang } \\
\text { dinazarkan }\end{array}$ & $\begin{array}{l}\text { 9. Ibadah yang } \\
\text { bersangkutan dengan } \\
\text { kemaslahatan dunia yang } \\
\text { mempunyai nilai-nilai } \\
\text { pahala }\end{array}$ & $\begin{array}{l}\text { Menjaga } \\
\text { kebersihan } \\
\text { lingkungan, aksi } \\
\text { sosial dalam } \\
\text { bencana alam }\end{array}$ \\
\hline $\begin{array}{l}\text { 10. lbadah yang } \\
\text { wajib segera } \\
\text { dilaksanakan } \\
\text { apabila telah sampai } \\
\text { kadarnya. }\end{array}$ & $\begin{array}{l}\text { Zakat binatang, } \\
\text { emas dan zakat } \\
\text { tumbuh- } \\
\text { tumbuhan }\end{array}$ & & \\
\hline
\end{tabular}

\section{Metode Pendidikan Ibadah}

Dalam pembahasan metode ibadah ini, Hasbi Ash Shiddieqy mengkaji beberapa metode yang dapat menghasilkan kajian bersifat ilmiah seperti yang diharapkan. Dari pengkajiannya menggunakan tiga metode sebagai berikut:

a. Metode Istidlal

Metode ini menggunakan metode Karomah madzhab dengan langkah-langkah sebagai berikut:

1. Hendaklah dipilih soal yang penting, lalu diterangkan pendapat para Mujtahidin, terutama pendapat imam-imam yang empat. 


\section{Abdul Kahar}

2. Hendaklah dikemukakan hujah-hujah yang dipegangi oleh masing-masing imam dan cara-cara mereka beristidlal.

3. Hendaklah dikemukakan dasar dan kaidah yang dipegangi oleh imam tersebut. Dengan demikian, mahasiswa-mahasiswa dapat membandingkan pendapatpendapat itu satu sama lain dan mereka dapat mengetahui dalil-dalil atau pegangan para mujtahid.

4. Hendaklah mahasiswa dituntun kepada kesanggupan untuk mengkritik dan menyelidiki pendapat imam madzhab.

\section{b. Metode Qudwah}

Metode ini mencontohkan langsung dengan menjelaskan secara detail dalam satusatu perkara ibadah. Contohnya dalam melaksanakan shalat, Hasbi Ash Shiddieqy menjelaskan mulai dari Thaharah beliau jelaskan hingga rinci bagaimana cara melakukan taharah atau wudhu yang baik. Begitu pula dengan shalat, secara berurutan Hasbi menjelaskan. Mulai dari takbir, bagaimana mengangkat tangan ketika takbiratul ihram hingga sampai ketika salam, yang terpenting ibadah shalat dilakukan adalah secara tuma'ninah yang sempurna agar ibadah yang dilakukan tidak menjadi sia-sia. Menjadi khusyuk dalam ibadah itu adalah hal yang dianjurkan bahkan wajib, agar ibadah menjadi sempurna Sebagaimana Allah berfirman dalam surat Al-Baqarah, ayat 45.

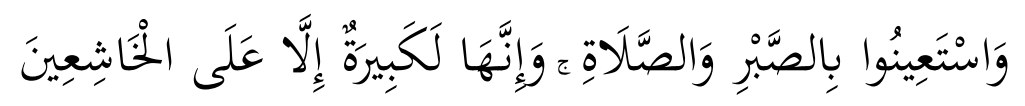

"Carilah pertolongan dengan kesabaran dan shalat, dan sesungguhnya shalat itu sungguh besar (berat) melainkan atas orang-orang yang khusyuk

Ayat ini menunjukkan bahwa sungguh tercela orang-orang yang tidak khusyuk. Dicelanya orang yang tidak khusyuk, memberi pengertian bahwa khusyuk adalah wajib. Di antara yang diyakini dengan mudah mengenai khusyuk dalam ayat di atas, adalah khusyuk dalam shalat.(Shiddieqy, 2010)

\section{c. Metode Targhib dan Tarhib}

Ada beberapa gambaran yang dijelaskan dalam metode targhib dan tarhib ini, terhadap pembalasan atas orang-orang yang melaksanakan shalat dan meninggalkannya. Beberapa metode tersebut Hasbi Ash Shiddieqy menjelaskan bahwa:

1. Orang yang menzalimkan diri yaitu orang yang sangat berlaku ceroboh terhadap shalatnya, yakni tidak menyempurnakan wudhunya, tidak menjaga waktuwaktunya, batasan-batasannya dan rukun-rukunnya. Imbalan yang diperoleh adalah siksa. 
2. Orang yang menjaga dan memelihara waktu-waktunya, batasan-batasannya, rukunrukunnya yang zhahir, juga whudhunya, semua tidak melawan nafsunya yakni tidak melawan gubrisan-gubrisan di dalam hatinya, bershalat dalam keadaan waswas dan aneka rupa pikiran yang mencederakan shalat. Imbalannya di buat perkiraan.

3. Orang yang memelihara segala batasan-batasannya dan rukun-rukunnya, serta berdaya upaya menolak waswas dan gubrisan-gubrisan hati dia, terus menerus berusaha melawan godaan agar tidak dapat mencederai shalatnya. Imbalannya dimaafkan.

4. Seluruh himmahnya dipergunakan dengan sepenuh hatinya untuk shalat, imbalannya mendapat pahala.

5. Orang yang apabila berdiri untuk shalat, hatinya penuh dengan rasa cinta dan kebesaran Allah swt. seakan-akan ia melihat Allah swt. dengan mata kepalanya. Waswas dan gubrisan-gubrisan hati tidak ada pada hatinya hijab tersingkap antaranya Tuhannya. Imbalannya didekatkan kepada Allah. Keutamaan dan kebesaran golongan ini, lebih besar dari apa yang ada di antara langit dan bumi.(Shiddieqy, 2001)

6. Seseorang yang terus-menerus meninggalkan shalat dengan perasaan enteng, tidak merasa menyesal dan tidak merasa perlu bertobat, maka orang itu dipandang kafir. Karena meninggalkan shalat yang semacam ini, meniadakan iman. (Shiddieqy, 2001)

Beberapa metode inilah yang dijelaskan Hasbi Ash Shiddieqy, yang bisa menjadi ukuran bagi setiap muslim dalam melaksanakan ibadah. Allah telah memberi petunjuk dan pelajaran kepada manusia agar senantiasa selalu menjaga ketaatan dan ketakwaan kepada Allah melalui ibadah. Maka jika ibadah shalat ditinggalkan dengan sengaja atau tidak melakukan sama sekali, Allah akan memberi ganjaran siksa. Begitu juga bagi yang selalu menjaga dan melaksanakan

ibadah, maka Allah akan membalasnya dengan pahala. Semua ibadah yang dilakukan akan dibalas sesuai dengan apa yang diperbuat.

\section{Evaluasi Pendidikan Ibadah}

Sikap dan perilaku umat Islam terhadap shalat amat beragam, ada yang melaksanakan shalat dan ada yang tidak. Ada pula yang kadang-kadang shalat kadangkadang tidak, merasa tanpa berdosa apabila meninggalkan shalat. Hal ini menunjukkan bahwa tidak mengerti dengan perintah yang seharusnya wajib dilaksanakan.

Ada beberapa hal yang terdapat pada diri manusia yang melaksanakan ibadah yaitu:

Pertama, terciptanya jiwa yang jernih, dengan membaca kitabullah dan membaharui ingatan kepada-Nya dan menambah terhunjamnya iman ke dalam lubuk jiwa dengan jalan bermunajat dengan Tuhan yang mempunyai kekuasaan dan kebesaran. 
Kedua, membesarkan Tuhan yang disembah, amalan-amalan shalat mengandung pekerjaan-pekerjaan yang nyata mewujudkan kesempurnaan khudhu' dan kesempurnaan ta'dhim. Ketiga, menjauhkan diri dari fahsya dan munkar, yang demikian ini dilakukan dengan ucapan dan perbuatan. Para Mushollin menghindarkan sifat jelek dari dirinya dengan gerakan-gerakan shalat. Yakni apabila seseorang telah bisa melaksanakan shalat dengan khusyuk dan khudhu', tertanamlah dalam jiwanya cinta kepada kebajikan. Inilah yang merupakan kandungan firman Allah Swt. dalam surat AlAnkabut, ayat 45

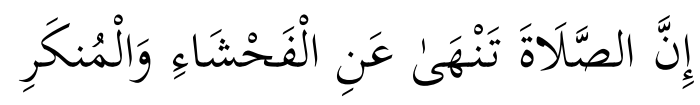

"Laksanakanlah shalat, sesungguhnya shalat itu mencegah (dari perbuatanperbuatan) keji dan munkar”.

Sifat jelek yang terbesar adalah mengingkari adanya Tuhan dan sebesar-besar munkar adalah mempersekutukan Tuhan. Apabila orang yang melakukan shalat masih melakukan perbuatan yang jelek dan tidak berubah akhlaknya maka berarti belum sempurna shalatnya. Dan bila orang-orang yang telah berubah perilakunya dengan baik maka sudah bagus shalatnya. Baik buruknya perilaku seseorang tergantung pada amal ibadah yang dia kerjakan. Hasilnya dapat dilihat dari firman Allah di atas yang telah jelas.

\section{KESIMPULAN}

Pendidikan ibadah menurut Muhammad Hasbi Ash Shiddieqy merupakan suatu usaha untuk memberikan kesadaran dalam beribadah kepada manusia agar mengerti eksistensi dirinya sebagai hamba Allah. Landasannya bersumber kepada dua sumber dasar yaitu Al-Qur'an dan Hadits. Tujuannya ialah ibadah hak Allah dan wajib dipatuhi, ibadah ghayah (tujuan) hidup manusia, dan ibadah sebagai perintah. Kurikulumnya ada dalam bentuk ibadah mahdah dan ghairu mahdah. Metodenya dengan cara istidlal, qudwah, targhib dan tarhib. Evaluasinya dengan cara melihat akhlaknya, jika akhlaknya bagus maka bagus ibadahnya dan jika akhlaknya rusak berarti harus diperbaiki kembali ibadahnya. Secara umum pemikiran Hasbi Ash Shiddieqy dalam pendidikan ibadah sangat relevan dengan pendidikan Islam, dari pengertian pendidikan yang sama dan juga landasan yang tidak berbeda serta tujuannya, kurikulum, metode dan evaluasinya. 


\section{DAFTAR PUSTAKA}

Ikhtiono, G. (2018). PENDIDIKAN SEBAGAI PROSES PENYIAPAN WARGA NEGARA. Tawazun: Jurnal Pendidikan Islam, 8(1), 71-82.

Indonesia, M. P. R. (1993). GBHN 1993 - 1998 / TAP / MPR / NOMOR II MPR 1993. Jakarta: Sinar Grafika.

Kulsum, U. (2002). Pengaruh Disiplin Ibadah Shalat Terhadap Prestasi Belajar Siswa SMU NEC. 1, SMU NEG. 5, Dan SMU NEG. 7 Kota Bogor,. Universitas Ibn Khaldun Bogor.

Nahlawi, A. A. (1989). Prinsip-Prinsip dan Metode Pendidikan Islam. Bandung: Diponegoro.

Qardhawi, Y. Al. (1993). Bagaimana Memahami Hadits Nabi saw. (M. al-Baqir, Trans.). Bandung: Karisma.

Rahman, F. (1991). Ikhtiar Musthalahul Hadits. Bandung: al-Ma'arif.

Razak, N. (1984). Dinul Islam. Bandung: al-Ma'arif.

Shiddieqy, M. H. A. (1994). Koleksi Hadits-hadits Hukum Jilid 1. Jakarta: PT Magenta Bhakti Guna.

Shiddieqy, M. H. A. (2001). Pedoman Shalat. Semarang: Pustaka Rizki Putra.

Shiddieqy, M. H. A. (2010). Kuliah Ibadah. Semarng: Pustaka Rizki Putra.

Shiddieqy, M. H. A. (2012). Sejarah dan Pengantar Ilmu Al-Qur'an dan Tafsir. Semarang: PT. Pustaka Rizki Putra.

Shihab, M. Q. (1998). Wawasan Al-Qur'an. Bandung: Mizan.

Tirmidzi, I. (n.d.). Sunan Tirmidzi. Beirut: Darul Fikri. 